\title{
Effect of Mothers' Work on Psychological Well-Being of Their Children at Benha City
}

\section{Aya Said Ramdan ${ }^{1}$, Sayeda Ahmed Abd Elatif ${ }^{2}$, Mawaheb Mahmoud Zaki ${ }^{3}$ and Hend Ahmed Mostafa $^{4}$}

(1) Nursing Supervisor at Shbein-Elkom Neurosurgery Hospital, (2) Professor of Psychiatric and Mental Health Nursing, Faculty of Nursing, Cairo University, (3) Assistant professor of psychiatric and Mental Health Nursing, Faculty of Nursing, Benha University and (4) Lecturer of Psychiatric and Mental Health Nursing, Faculty of Nursing, Benha University.

\begin{abstract}
Back ground: Children face several cognitive, behavioral and psychological effects that are the result of maternal employment during their early developmental years. Aim: Study aimed to assess the effect of mothers' work on psychological well-being of their children at Benha city. Research Design: A descriptive design was utilized to fulfill the aim of the study .Setting: This study was conducted at selected governmental primary schools at Banha city, Qaliubiya government. Sample: A multistage sample included 400 children selected from the above mentioned settings .Tools of data collection: Tool (1): A structured interviewing questionnaire sheet, tool (2): The Stirling Children's Wellbeing Scale. Results: Less than half of the studied sample had low level of total psychological wellbeing and less than one third had moderate level while one fifth of them have high level of total psychological wellbeing .Conclusion: Mothers' work had a negative effect on the psychological wellbeing of their children. Recommendations: Developing awareness programs for enhancing woman's knowledge for improving psychological well-being of their children.
\end{abstract}

Key words: Working mothers, Psychological wellbeing, Children.

\section{Introduction}

Working mothers experience a lot of stress which arise from the inability to balance between work and family needs. These two responsibilities appear to be like two jobs which are being handled by one person at the same time. As a result, these mothers are ever in a hurry to catch up with time and attend to unfinished duties at home and at work place. These mothers end up meeting the needs of the family with very few men willing to share the responsibility. In the event that a child falls sick, mothers find it difficult to fully attend to the child at the expense of her sleeping job. They also feel stressed over their own lives. Many working women are not willing to give birth. In other words, working continues to rob women off their mothering ability (Pollmann\& Hess, 2020).

Moreover, working mother enters the workforce and stay there; more and more children are cared for by adults other than their parents. Relatives sometimes take on child care duties, or children are cared for in a variety of child care settings. Not surprisingly, working mothers are more likely to have their infants and toddlers in an out-ofthe- home child care center than nonemployee mothers. The problems start when the child may feel alone and fall in bad company in search for friendship and affection, being alone in their house for most of the time. The parents do not have time to attend the 
important school meetings, functions, outings or talk to the child about his problems, which may develop guilt, inferiority or he may end up having depression in worst cases (Ellemers,2018).

Children's well-being not only depends on their own emotional, social, and cognitive functioning, but also on environmental factors. Amongst these, familial factors, such as maternal working are particularly important and influential. Maternal well-being may possibly affect children's outcomes via its impact on parenting (Dillow, 2020).

\section{Significance of the study}

Children born of working mothers experience difficulties during their early stages of development. As young beings, children need enough time from their caregivers who are non-other their mothers. In the absence of this care emotional impact is felt which may affect up to the academic capabilities of such children (Martin , 2019)

Many studies have demonstrated the significant effects of maternal work on children's psychological well-being that reflected on their emotional status as they observed that the emotional disorders were reported $12-25 \%$ of school-age children and $13 \%$ of preschooler children's. The psychosocial problem increased from $6.8 \%$ to $18.7 \%$ and emotional problems showed the increase from to $0.2-3.6 \%$. These increase in psychosocial problems were associated with increase in the proportion of single-parent families, parents get divorced, mothers employment .The prevalence rate of anxiety among Egyptian primary school children were $7.9 \%$ and $15 \%$ had mixed anxiety and depressive disorders (Eassys,2018).

\section{Aim of this study}

The aim of this study was to assess the effect of mothers' work on psychological well-being of their children at Benha city.

\section{Subject and methods}

\section{Research Design:}

A descriptive design would be utilized in this study.

\section{Research Setting:}

This study was conducted at selected governmental primary schools at Benha city , Qaliubiya Government . As there are (20) governmental primary schools which are affiliated to Benha educational administration. A multistage random sample was used to select $50 \%$ of these primary schools (10) schools.

\section{Subject:}

\section{Sample Size:-}

A multistage random sample of (400) students was taken from the previously mentioned setting by taken randomly one grade from selected governmental primary governmental schools then taken all students from these grades.

\section{Sample Technique:-}

A multistage sample of 400 students from the above mentioned setting who will fulfill the following inclusion criteria:-

\section{Inclusion criteria:-}

- Age: (6-12) years.

- Children whose mother working.

- Both sexs.

- willingness to participate in the study

\section{Tools of data collection:}

The data were collected through using the following tools: 
Tool (1):-A Structured Interviewing Questionnaire Sheet: It was developed by the researcher and used to assess characteristics of studied children, their family and their parents.

\section{Tool (2):-The Stirling Children's Wellbeing Scale:-}

This scale developed by Liddle and Carter (2015), as a screening tool to asses' psychological well-being of children. The scale consists of 15 items that are divided into 3 subscales:-Positive emotional state (6 items), Positive Outlook (6items) and Social Desirability (3items).

\section{Validity of tools:}

To achieve the criteria of trust and worthiness of the tools of data collection in this study, the tools were tested and evaluated for their face and content validity, were tested by five experts in psychiatric and mental health nursing field.

\section{Reliability of tools:}

Reliability was applied by the researcher for testing the internal consistency of the tools, by administration of the same subjects under similar conditions on one or more occasions. Answers from related testing were compared (test-re-test reliability) by using Alpha cronbach reliability. The tool was strongly reliable at 0,93 for the striling children well-being scale

\section{Ethical consideration}

An oral consent was obtained from the studied sample after explaining the purpose of the study. All subjects were informed that the participation in the study is voluntary and no name was to be included in the questionnaire sheet.

\section{Field work}

The actual filed work was carried out in about 3 months from the middle of October 2020 to the end of December 2020. The researcher visited the selected governmental primary schools at Benha city from 9 am to $1 \mathrm{pm}$, 3days per week to collect data from children An individual interview was conducted for every children to collect the necessary data using the tools for data collection attitude related to psychological wellbeing scale. The average time needed for this sheet was around (25-30) minutes. The researcher visited this selected governmental primary schools 3/ days per weeks and be stressed in data collection due to (COVID- 19 disease)

\section{Statistical analysis:}

The statistical analysis of data was done by using the computer software of Microsoft Excel Program and Statistical Package for Social Science (SPSS) version 20. Data were presented using descriptive statistics in the form of frequencies and percentage for categorical data, the arithmetic mean (X) and standard deviation (SD) for quantitative data. Qualitative variables were compared using chi square test (X) 2, P-value to test association between two variables and $\mathrm{R}$ - test to the correlation between the study variables.

\section{Degrees of significance of results were considered as follows:}

- P-value >0.05 Not significant (NS)

- P-value $\leq 0.05$ Significant (S)

- P-value $\leq 0.01$ highly statistically Significant (HS) 


\section{Results}

Table (1) shows that, less than half (42\%) of the studied children their age ranged between 10-12 years, the Mean SD of age was 9.35 \pm 3.64 year. As regard to gender, more than half $(53.5 \%)$ of the studied children were females. Also, less than one-quarter $(22.5 \%)$ of the studied children were at Fifth grade. Concerning residence, the majority $(82 \%)$ of them are living in urban areas. Regarding family type, less than two-thirds $(63.5 \%)$ of the studied children had independent family. Also, more than two-thirds of the studied children had 4-6 people in their family while more than half of them had 1-2 siblings, (70.5\% and $61.5 \%)$ respectively. Concerning ranking among family members, less than one-third $(31.3 \%)$ of the studied children were the second child

Table (2) illustrate that less than half (43.8\%) of the studied children their mothers' age ranged from 35-<40 years, the Mean SD of mothers' age was $37.61 \pm 3.60$ year. Also, more than one-third and more than half of the studied children their mothers were employee at government and had secondary education (diplome) (38.3\% and 57\%) respectively. Also, less than half (44\%) of the studied children their mother working from $8-<10$ hours with Mean SD 9.19 \pm 2.59 hours.

Table (3) shows that there is a high statistically significant relation between all children's psychological well-being subscales and their mothers' work at $(\mathrm{P}$ value $=<$ $0.01 * *)$.

Table (4) shows that there is a highly significant positive correlation between children's positive emotional state and their positive outlook and social desirability at $(\mathrm{P}$ value $\left.=<0.01^{* *}\right)$. 
Table (1): Socio-demographic characteristics of the studied children and their families

\begin{tabular}{|c|c|c|}
\hline $\begin{array}{l}\text { Socio-demographic Characteristics of the studied children and their } \\
\text { families. }\end{array}$ & $\mathbf{N}$ & $\%$ \\
\hline \multicolumn{3}{|c|}{ Age (year) } \\
\hline $6-<8 \quad$ years & 98 & 24.5 \\
\hline $8-<10$ years & 134 & 33.5 \\
\hline 10-12 years & 168 & 42 \\
\hline \multicolumn{3}{|c|}{$9.35 \pm 3.64$} \\
\hline \multicolumn{3}{|l|}{ Gender } \\
\hline Male & 186 & 46.5 \\
\hline Female & 214 & 53.5 \\
\hline \multicolumn{3}{|l|}{ Academic grade : (primary) } \\
\hline First grade & 50 & 12.5 \\
\hline Second grade & 52 & 13 \\
\hline Third grade & 70 & 17.5 \\
\hline Fourth grade & 66 & 16.5 \\
\hline Fifth grade & 90 & 22.5 \\
\hline Six grade & 72 & 18 \\
\hline \multicolumn{3}{|l|}{ Residence } \\
\hline Rural & 72 & 18 \\
\hline Urban & 328 & 82 \\
\hline \multicolumn{3}{|l|}{ Family type } \\
\hline Independent & 254 & 63.5 \\
\hline Extended & 146 & 36.5 \\
\hline \multicolumn{3}{|l|}{ Number of people in the family } \\
\hline$<4$ & 78 & 19.5 \\
\hline $4-6$ & 282 & 70.5 \\
\hline$>6$ & 40 & 10 \\
\hline \multicolumn{3}{|l|}{ Number of brothers /sisters } \\
\hline $1-2$ & 246 & 61.5 \\
\hline $3-4$ & 130 & 32.5 \\
\hline$>4$ & 24 & 6 \\
\hline \multicolumn{3}{|l|}{ Ranking among family members } \\
\hline The First & 98 & 24.5 \\
\hline The second & 125 & 31.3 \\
\hline The third & 110 & 27.5 \\
\hline The last & 67 & 16.8 \\
\hline
\end{tabular}


Table (2): Percentage distribution of the studied sample according to their mother's characteristics $(n=400)$.

\begin{tabular}{|c|c|c|}
\hline Mother's characteristics & $\mathbf{N}$ & $\%$ \\
\hline \multicolumn{3}{|l|}{ Mothers' age } \\
\hline $25-<30$ years & 84 & 21 \\
\hline $30-<35$ years & 92 & 23 \\
\hline $35-<40$ years & 175 & 43.8 \\
\hline$\geq 40 \quad$ years & 49 & 12.2 \\
\hline Mean SD & \multicolumn{2}{|c|}{$37.61 \pm 3.60$} \\
\hline \multicolumn{3}{|l|}{ Mothers' education level } \\
\hline Illiterate & 16 & 4 \\
\hline Read \&Write & 20 & 5 \\
\hline Primary /preparatory & 60 & 15 \\
\hline Secondary education (dipome) & 228 & 57 \\
\hline High education & 60 & 15 \\
\hline Postgraduate & 16 & 4 \\
\hline & \multicolumn{2}{|c|}{ Mothers' work } \\
\hline Employee at government & 153 & 38.3 \\
\hline Employee at private sector & 110 & 27.5 \\
\hline Free business & 42 & 10.5 \\
\hline Other & 95 & 23.7 \\
\hline \multicolumn{3}{|c|}{ Number of working hours for your mother } \\
\hline $6-<8$ & 1119 & 29.8 \\
\hline $8-<10$ & 176 & 44 \\
\hline$\geq 10$ & 105 & 26.2 \\
\hline Mean SD & \multicolumn{2}{|c|}{$9.19 \pm 2.59$} \\
\hline
\end{tabular}

\section{Total level of psychological well-being}

Figure (1): Percentage distribution of the studied children according to their total psychological wellbeing scale 
Table (3) Relationship between mother's work and total psychological well-being subscales among studied sample $(n=400)$.

\begin{tabular}{|c|c|c|c|c|c|c|c|c|c|c|c|c|}
\hline \multirow{3}{*}{\multicolumn{2}{|c|}{$\begin{array}{c}\text { Levels of total } \\
\text { psychological well-being }\end{array}$}} & \multirow{4}{*}{$\begin{array}{l}\mathbf{N} \\
\\
80\end{array}$} & \multicolumn{8}{|c|}{ Mothers' job } & \multirow{3}{*}{$\mathbf{X} 2$} & \multirow{3}{*}{$\begin{array}{c}\text { P- } \\
\text { Value }\end{array}$} \\
\hline & & & \multicolumn{2}{|c|}{$\begin{array}{l}\text { Employee at } \\
\text { government }\end{array}$} & \multicolumn{2}{|c|}{$\begin{array}{l}\text { Employee } \\
\text { at private } \\
\text { sector }\end{array}$} & \multicolumn{2}{|c|}{$\begin{array}{c}\text { Free } \\
\text { business }\end{array}$} & \multicolumn{2}{|c|}{ Other } & & \\
\hline & & & $\mathbf{N}$ & $\%$ & $\mathbf{N}$ & $\%$ & $\mathbf{N}$ & $\%$ & $\mathbf{N}$ & $\%$ & & \\
\hline \multirow{3}{*}{$\begin{array}{c}\text { Positive } \\
\text { emotional } \\
\text { state }\end{array}$} & High & & 0 & 0.0 & 9 & 11.2 & 38 & 47.5 & 33 & 41.3 & \multirow{3}{*}{14.15} & \multirow{3}{*}{$.001 * *$} \\
\hline & Moderate & 120 & 24 & 20 & 72 & 60 & 4 & 3.3 & 20 & 16.7 & & \\
\hline & Low & 200 & 129 & 64.5 & 29 & 14.5 & 0 & 0.0 & 42 & 21 & & \\
\hline \multirow{3}{*}{$\begin{array}{l}\text { Positive } \\
\text { Outlook }\end{array}$} & High & 84 & 2 & 2.4 & 8 & 9.5 & 42 & 50 & 32 & 38.1 & \multirow{3}{*}{14.05} & \multirow{3}{*}{$.001 * *$} \\
\hline & Moderate & 110 & 8 & 7.3 & 80 & 72.7 & 0 & 0.0 & 22 & 20 & & \\
\hline & Low & 206 & 143 & 69.4 & 22 & 10.7 & 0 & 0.0 & 41 & 19.9 & & \\
\hline \multirow{3}{*}{$\begin{array}{c}\text { Social } \\
\text { desirability }\end{array}$} & High & 88 & 6 & 6.8 & 12 & 13.6 & 40 & 45.5 & 30 & 34.1 & \multirow{3}{*}{13.97} & \multirow{3}{*}{$.005^{* *}$} \\
\hline & Moderate & 145 & 43 & 29.7 & 78 & 53.8 & 2 & 1.4 & 22 & 15.2 & & \\
\hline & Low & 167 & 104 & 62.3 & 20 & 12 & 0 & 0.0 & 43 & 25.7 & & \\
\hline \multirow{3}{*}{$\begin{array}{c}\text { Total } \\
\text { psychological } \\
\text { well-being }\end{array}$} & High & 82 & 0 & 0.0 & 7 & 8.5 & 40 & 48.8 & 35 & 42.7 & \multirow{3}{*}{14.17} & \multirow{3}{*}{$.001 * *$} \\
\hline & Moderate & 126 & 24 & 19 & 80 & 63.5 & 2 & 1.6 & 20 & 15.9 & & \\
\hline & Low & 192 & 129 & 67.2 & 23 & 12 & 0 & 0.0 & 40 & 20.8 & & \\
\hline
\end{tabular}

*significant at $p<0.05$. **highly significant at $p<0.01$

Table (4): Correlation between children's psychological well-being subscales.

\begin{tabular}{|r|c|c|}
\hline $\begin{array}{c}\text { Correlation between children } \\
\text { psychological wellbeing subscales }\end{array}$ & Positive emotional state & Positive Outlook \\
\hline Positive emotional state & & $\mathrm{r}=544$ \\
$\mathrm{P}=.000^{* *}$
\end{tabular}

\section{Discussion}

In addition, Wazqar et al., (2017) who showed that the age group of the majority of the children in their studies was between 6to 12 years old.

As regard to gender, more than half of the studied children were females . This might be due to increase birth rate of females rather than males. This finding was similar to the study done Juboori (2019) who found that the majority of his samples were females.

Concerning residence, the majority of the studied children are living in urban areas this might be due to jobs chances, better living condition and a lot of schools and hospitals. This finding was similar to the study done by Arabaci (2019) who found that the majority of his samples preferred living at urban areas. On the same line, Akinjola (2018) who reported that, more than half of 
his samples were living at urban areas with better live condition.

Regarding to number of brothers and sisters more than half of the studied children had 1-2 siblings (brothers and sisters). This finding might be due to increase birth rate generally at Egypt. Also, more than twothirds of the studied children had 4-6 people in their family. This finding was similar to the study done by Dagget (2018) who revealed that the majority of their samples had 1-2 siblings (brothers and sisters).

On the other hand, these results contradicted those of Juboori (2019) who showed that, more than half of his studied children were the only child and did not had any siblings (brothers and sisters) at home.

The current study results demonstrated that more than half of the studied children had independent family. These results could be due to work of both father and mother of children and other relatives take care of their children which effects on their psychological well-being. These findings were similar to the study done by Mula (2018) who found that the majority of children of the working mother in his studies have independent family.

On the other hand, these results contradicted those of Kelleher (2019) who indicated that, the majority of participants were living at extended families.

The present study results demonstrated that less than half of the studied children their mothers' age ranged from $35<40$ years. This might be due to the fact that this age is the age of working mother who start to work after the birth of child to support the economic condition of her family these findings were consistent with the study done by Feghhi (2018) who indicated that most of his samples were in the age group: 35-40 years. These findings also were similar to the study done by Juboori (2017) who showed that, more than half of

In contrast, these findings were in disagreement with Vahedi (2018) who found that: the age of in his study samples working mother were ranged from (15:65) years old.

The present study reflected that more than half of mother of the studied children had secondary education (diplome) .This could be explained by the fact that mothers preferred secondary education (diplome) because they finish education after years and start to work compared with high education which need more years to finish and finally both get the same job. These findings was similar to Abbas (2017) who found that more than half of mother of the studied children had secondary education (diplome) .These data are in contrast to the study conducted by Juboori (2019) who found that the majority of his samples preferred to continue their education and get high education level.

The present study results reflected that, more than one-third and more than half of the studied children their mother are employee at government., this result could be related to the fact that a lot of working mother prefer to work at governmental sector which allow to making part-time tenures available. In addition governmental sector had flexible working hours which not allowed at the private sector which help mothers to make a balance between their work and their families

These findings were similar to study done by Stoops (2018), who found his result were majority of samples working within governmental sector with consistent time to attendees and leaving the work. These results were in disagreement with Cotter (2019) who indicated that more than half of mothers of his studied samples working at private sector 
with better income rather than the governmental sector. Also Chang (2019) who reflected that, the majority of his samples were working on private sector with better contracts rather than the governmental sector.

The current study findings showed that, near the half of the studied children their mother working from $8-<10$ hours with Mean SD $9.19 \pm 2.59$ hours. This result could be related to the average of the number hours of work according to the Egyptian work low which ranged from (6-10) hours per day. These findings were consistent with Research findings revealed by Amanda (2018) who demonstrated that less than half of his studied sample working 8-10 hours. On the same line Yang (2017) who reported that more than half of studied children their mothers working 810 hours per day. These findings were in disagreement with Xuel (2019) who reported that more than half of his samples working more than 12 hours per day for better income and live condition.

The present study findings demonstrated that less than half of the studied primary school children had low level of total psychological well-being and also less than the one third had moderate level of total psychological well-being. This could be due to the negative effects of mothers' work on emotional, social, cognitive and psychological development of their children as mothers were fundamental persons in developing their children healthy and enjoying good mental and psychological state.

This findings were similar to Akinjola(2018) who reported that the majority of his studied samples had low psychological wellbeing as a result of mothers' work. Moreover, Parel (2019) who reported that Mothers' employment affects the emotional development of children. As he stated that a mother who leaves her child in the care of others whole the day causes psychological and mental disturbance because none can equalize the love and care, their children always not feel cheerful about things and do not enjoy what each new day brings.

In addition, this findings in consistent with the study conducted by Cardas (2018) who revealed that maternal work was positively associated with the children's emotional problems and psychological problem with in the children. Also Ceulemans (2019) who reported that more than half of of his studied samples had low level of total psychological well-being.

Furthermore, This current findings were in similar to the study conducted by Desai (2020) who revealed that the majority of children who studied do not like all those they met and do not share with others the positive events in their lives related to some felling of discomfort and had low psychological well-being level.

Moreover, Kurtz (2018) who reported that larger negative effects on communication and social skills of children with working mother more than children with non-working mother. Also his study similarly found that when mothers went to work in the first years of their children's lives, or worked longer hours the children had high score of communication problem with other children which negatively affect their psychological well-being. Additionally, the present study results were in agreement with Waldfogel (2016) whose results were the majority of studied children with mother's job-related stress they also suffered from felling of stress, discomfort, and low social and communication skills and low psychological well-being level. 
On the other hand, the study findings were in disagreement with Amanda (2018) who found that a majority of working mothers (seventy percent) felt that their employment had a positive impact on their child. In addition, ten percent felt that their employment had a negative effect and twenty percent felt it had no effect. On the same line Selo-Ojeme (2017) who reported that, children with continuous exposure to stress and responsibilities related to not presence of their mothers make them more able to face any challenge or problem during their lives. Also Hickam (2016) who found that, majority of his studied samples were had normal level of psychological well-being.

The present study showed that, there was a relationship between mothers' work and total psychological well-being subscales among studied sample and reflects that there is a high statistically significant relation between all children's psychological well-being subscales and their mothers' work. This might be due to that the bond between mother and children is critical and affect the early psychological and emotional well-being of her children.

On the same line Cotter (2019) who reported that more ever negative impact on children development Poor-quality day care services can hamper a child's emotional and social development. These findings were in disagreement with Parel (2019) who found that, there was not association between mothers' work and total psychological wellbeing of her children as being a working mother is a good successful model for your young children and they always try to do this.

The current study showed that, there was a correlation between children's psychological well-being subscales, explained that there is a highly significant positive correlation between children's positive emotional state and their positive outlook and social desirability. This study was similar with Matthias (2020) who found that there was a correlation between children's positive emotional state and their positive outlook and social desirability.

\section{Conclusion}

Mothers' work had a negative effect on psychological wellbeing of their children as less than half of the studied primary school children had low level of total psychological wellbeing and less than one third of them had moderate level while one fifth of them had high level of total psychological well-being.

\section{Recommendations}

- Developing continuous educational programs for working mothers to enhance their knowledge and practices regarding psychological well-being of children.

- Improving parent's awareness regarding early psychological and emotional development of their children and involving them in educational programs to encourage them to better communication with their children.

- Integrate the guidelines to the curriculum of student' children to learn how to face stress and anxiety felling be further applied into their lives.

\section{Acknowledgements}

- The author is so grateful to all children who agreed and participated in this study for their kind and cooperation.

- The author is also so grateful to the directors of Banha selected governmental primary schools for their permission to carry out this study. 


\section{References:}

Abbas .,p.(2017). Well-Being of Children and Families (New York: Russell Sage Foundation.55-665.

Akinjola.,X.(2018). Parental Employment and Child Cognitive Development," Journal of Human

Amanda.,E. (2018). Cognitive and behavioral Effects on Children Journal of The Four-Day Work Week.55-65.

Cardas .,L (2018). negative effect of mothers' work on their children. Journal of Employment Characteristics of Families.767-990.

Ceulemans.,W.(2019). the association between parenting style and socioemotional and academic functioning. Journal of childhood .33-55.

Chang.,O (2019). work conflict and quality of life. Journal of work. (1)23-23.

Cotter .,Z(2019). associations between parental employment and child wellbeing.450-650.

Dagget.,F. (2018).Associations between Mothers' Work, Family Conflict and Children's Psychological Wellbeing.232-444.

Desai.,U.(2020) : work Lives Affect Kids' Growth. Maternal Work Early in the Lives of Children and Its Distal.43:5588.

Ellemers,N.(2018).Gender stereo types .Annual review of psychology,annualreviews.org.

Essays,U.(2018). working mothers negative effects on Young children Social work Eassay.Retrived from https://www.ukessays.com/essays/social work eassay,Accessed on 5-1-2020 at 5 p.m.

Feghhi .,Y.(2018). Shonkoff and Deborah A. Phillips, eds., From Neurons to Neighborhoods: The Science of Early.

Hickam ., M.(2016). What Children Need (Cambridge, MA: Harvard University Press, 2016).

Juboori.,w.(2019).employment Characteristics of families Journal of childhood .33-55.

Kelleher.,K. (2019). negative maternal and paternal parenting styles as predictors of children's behavioral problems.(3)5578.

Kurtz .,M.( (2018). Journal of Maternal Work Early in the Lives of Children and Its Distal.454-665.

Martin ,O.(2019). The work-family interface: A retrospective look at 20 years of research in JOHP. Journal of Occupational Health Psychology 22 (3), 259.

Matthias.,L. (2020). Developmental Risks (Still) Associated with Early Childcare.12-123

Mula.,K. (2018). Journal of Maternal Work Early in the Lives of Children and Its Distal.454-665.

Parel.,m. (2019). Associations with Achievement and Behavior Problem. Journal of Human Resources .88-99. Resources 39: 155-92.

Pollmann ,M., Hess ,S.(2020).Associations between mothers' work-family conflict and children's psychological wellbeing: The mediating role of mothers' parenting behavior.Journal of Child and Family Studies 29 (6), 1561-1571 
Selo-Ojeme.,L (2018).who study the new working mother and her child.(7)676787.

Stoops.,O. (2018)). Maternal employment. Journal of Parental Employment and Child Cognitive Development," Journal of Human Resources 39 :155-92.

Vahedi.,O.(2018). Employment Characteristics of Families.Journal of childhod Risks.332-465.

Waldfogel .,q.(2016). the harried Life of the working mother. Journal of Developmental Cognitive Neuroscience: 44-55.

Xuel.,P (2019). Effects of Infant-Mother and Infant-Father Attachments," Child Development $58: 1505-12$.

Yang .,P. (2017). Effects of Infant-Mother and Infant-Father Attachments," Child Development $58: 1505-12$. 


\section{تاثير عمل الامهات على الرفاهيه النفسيه لأطفالهن فى مدينة بنها}

$$
\text { ايه سعيد رمضان - سيدة أحمد عبد اللطيف ـ مو اهب محمود زكى - هند أحمد مصطفى }
$$

عمل الأم له تأثثر سلبي على الصحة النفسية لأطفالها حيث يؤثر عمل الام على الرفاهيه النفسيه للطفل حيث ان الام اهى المسؤله عن تقديم الرعاية الأساسيه للاطفال في سنواتهن الأولى من الحياه •وبسبب عمل الام لوحظ تقصير في المر اقبة والإشر اف في معظم العائلات التي تعمل فيها الأمهات ممايؤثز على الصحه النفسيه للاطفال ويتسبب لهم فى الثعور بفقدان الثقه بالنفس · اجريت هذه الدراسة على عدد · . ع طالب فى المدارس الإبتدائية الحكومية المختارة فى مدينة بنها محافظة القليوبية ، حيث كثفت النتائج عن وجود دلاله احصائيه العلاقه بين عمل الامهات و الرفاهيه النفسيه لاطفالهن. كما اوصت الدراسه عمل برامج تعليميه للامهات العاملات لامدادهن بالمعلومات اللازمه لرفع الرفاهيه النفسيه لاطفالهن • 